\title{
Justyna OLKO
}

University of Warsaw

jolko@al.uw.edu.pl

\section{LANGUAGE ENCOUNTERS: TOWARD A BETTER COMPREHENSION OF CONTACT-INDUCED LEXICAL CHANGE IN COLONIAL NAHUATL}

ABSTRACT The extensive corpus of colonial Nahuatl texts lights on almost every sphere of colonial life and cross-cultural interactions between the Europeans/Spaniards and the indigenous world. This corpus contains rich language data related to contact-induced change that reveal a simultaneous, prolonged use of neologisms and loanwords, a widespread "Nahuatlization" of foreign terms as well as adoption of Spanish ideas and cultural stereotypes. The linguistic phenomena discussed in the present paper focus on lexical change, neologization, meaning change, borrowing and the creation of calques. These language innovations reveal the nuances of the complex process of cross-cultural translation, the receptivity of European influence, the domestication of the new and the survival of traditional language resources.

Keywords: Nahuatl, Spanish, language contact, language change, colonial period, cross-cultural transfer

Palabras clave: Náhuatl, español, contacto lingüístico, cambio lingüístico, periodo colonial, transferencia intercultural 


\section{CONTACT-INDUCED CHANGE IN COLONIAL NAHUATL: INTRODUCTION}

The Nahua world provides an exceptional case-study for the exploration of long-term cross-cultural transfers and native response to European colonization. One of the most important culture groups of Mesoamerica, the Nahuas, occupied primarily the area of central Mexico, where they coexisted with speakers of other languages. Nahuatl enjoyed great importance in the pre-Hispanic world over a long stretch of time, and unlike many other indigenous languages, its speakers have survived in significant numbers to our days. In the time of the Spanish conquest they formed numerous local ethnic states (altepetl), most of which before 1519 bore some form of allegiance to the powerful organization of the Triple Alliance, often referred to as the Aztec empire by scholars today. After the fall of the empire in 1521, the local states survived not only in much of their political organization but in many other aspects of their culture in spite of becoming part of New Spain and the object of prolonged Hispanization. Nahuatl, serving as a lingua franca across Mesoamerica before the arrival of the Europeans on the scene, continued in importance as a language of colonization and Christianization. Although Spanish settlement centered on the Nahua culture area, across the following centuries native altepetl survived as the seats of Indian municipal government based on European models.

Having had a form of glyphic and even partly syllabic writing, the Nahuas started to write alphabetically very quickly, in the 1530 s and the 1540 s, less than two decades after the conquest. They have left a very rich and complex corpus of written texts that offers unique possibilities for studying cultural phenomena of the colonial period: historical annals, speeches, theatrical plays, petitions, assertions of local traditions and rights called "titles," religious texts (among them translations and reinterpretations of European sources) and a mass of everyday documentation including testaments, bills of sale, parish records, and censuses. This source base remains largely unparalleled on the American continents, even considering the substantial textual records left by other advanced cultures of the Mesoamerican region. The corpus sheds light on almost every aspect of colonial life and cross-cultural interactions, revealing the core of the concepts shared and developed by the native people, whether remaining the same as before contact, adopted from the Spaniards, or as perhaps most often, indigenous in origin but affected by Spanish, or Spanish in origin and affected by Nahuatl.

Scholarship that draws from this corpus has the potential to illuminate and grasp a thorough comprehension of the hitherto little recognized evolution of native concepts, practices and attitudes under Spanish influence in a vast temporal and geographical scope. Fundamental to any such comprehensive study of culture contact is the evolution of the language of these texts. As the focal point of interaction between native and European cultures across time and operating on different levels and among different groups of users, Nahuatl provides a framework for studying other cultural and socio-political phenomena seen as an utterly historical process. Extant native texts clearly show that it was the tool to name, describe, and conceptualize not only new pro- 
tagonists - be they conquistadors in the first phase of contact, members of religious orders, officials of the crown or of municipalities, ordinary Spaniards, Africans - but the whole cultural apparatus they brought with them - economic, religious, and legal practices and concepts, artifacts, materials, plants, and animals. As the tool and medium of expression in constructing the conceptual image of anything having to do with Spanish life, language was the very space of interaction. Given the extensive source base, the evolution of new language phenomena responding to culture contact, including not only the use of specific terms but also more subtle trends, can be followed decade by decade into the late eighteenth and sometimes even the nineteenth century, in different regions of the Nahua world and its peripheries. Moreover, specific trends and markers of change can be tracked across different genres of writing. Those, at least in some cases, can be correlated with distinct groups of people representing specific social groups and varying degrees of exposure to Spanish influence.

The pioneering research on Nahuatl in post-conquest times was done by Frances Karttunen and James Lockhart, ${ }^{1}$ who published the first listing of Spanish loanwords, analyzing their temporal appearance and phonetic adaptations, and finally postulating three main phases in the adaptation of Nahuatl to Spanish. This study was further developed by Lockhart, ${ }^{2}$ who broadened the content of the phases to include general sociocultural change under European impact, reflecting the increasing frequency and intensity of contact between Nahuas and Spaniards. He has been able to show that linguistic phenomena are one of the most sensitive indicators of the nature, extent, and trajectory of contact between the two cultures. Beginning with the creation of neologisms, descriptions and extensions of meaning, proceeding through an increasing borrowing of nouns, and culminating in the borrowing of verbs and particles as well as phonetic and syntactic assimilations, Lockhart's scheme reflects successive reactions to culture contact, marking an ongoing transformation. Four different general stages along with associated typological changes were proposed by Jensen, ${ }^{3}$ whereas other studies focused heavily Hispanized varieties of modern Nahuatl and specific cases of language displacement. ${ }^{4}$

In Lockhart's Stage 1, extending from the arrival of the Spaniards to ca. 1540-1550, Nahuatl remained almost unaffected. The Nahuas relied on the resources of their own

F. Karttunen, J. Lockhart, Nahuatl in Middle Years. Language Contact Phenomena in Texts of the Colonial Period, Berkeley 1976 (University of California Publications in Linguistics, 85).

2 J. Lockhart, The Nahuas after the Conquest. A Social and Cultural History of the Indians of Central Mexico, Sixteenth Through Eighteenth Centuries, Stanford 1992.

3 A. Jensen, 'Hispanisation in Colonial Nahuatl?' in T. Stolz, D. Bakker, R. Salas Palomo (eds.), Hispanisation. The Impact of Spanish on the Lexicon and Grammar of the Indigenous Languages of Austronesia and the Americas, Berlin-New York 2008 pp. 3-25 (Empirical Approaches to Language Typology, 39).

4 For example: U. Canger, Mexicanero de la Sierra Madre Occidental, México 2001 (Archivo de Lenguas Indígenas de México, 24); J.A. Flores Farfán, Cuatreros somos y toindioma hablamos. Contactos y conflictos entre el nábuatl y el español en el sur de México, Tlalpán, D.F. 1999 (Lengua-jes); idem, 'The Hispanization of Modern Nahuatl Varieties' in T. Stolz, D. Bakker, R. Salas Palomo (eds.), Hispanisation..., pp. 27-48; J. Hill, K.C. Hill, Speaking Mexicano. Dynamics of Syncretic Language in Central Mexico, Tucson 1986. 
language to describe the new, resorting to neologisms or extensions of meaning. During Stage 2, dating approximately from the mid sixteenth to the mid seventeenth century, the language underwent few changes in terms of morphology, syntax and phonology despite the widespread borrowing of Spanish nouns. In Stage 3, which begins in the mid seventeenth century and continues to the present in communities where Nahuatl is still spoken, many simultaneous changes took place, including the borrowing of verbs and particles, the adoption of plural forms and sounds missing earlier in Nahuatl, and the creation of equivalence relationships. Contrary to earlier stages, introductions were no longer motivated solely by new objects and concepts, but by linguistic differences between Spanish and Nahuatl, The fourth, partly overlapping stage refers to the use of a heavily Nahuatlized version of Spanish, ${ }^{5}$ corresponding with the notion of interference through shift ${ }^{6}$ or imposition. ${ }^{7}$ Lockhart's framework roughly corresponds also to the concept of the "borrowing scale," ranging from casual contact (1) through two intermediate levels of more intense contact $(2,3)$ to intense contact (4) marked by heavy borrowing and structural change. ${ }^{8}$ The latter model emphasizes more the notion of the intensity of contact than its duration and longevity. The last two factors, however, appear to be crucial for reconstructing Nahuatl-Spanish interaction, in which the intensity of contact varied greatly between specific localities and regions. Although there are important indicators that language phenomena reflect a broader overall change attested in geographically separated regions with different degrees of exposure to cross-cultural contact, currently available sources imply that this picture is far from being uniform, especially if data from both modern and colonial sources are taken into account. Accordingly, the fact that local patterns of change pose a special challenge to the study of contact-induced change in Nahuatl suggests that they should to be examined in depth through the extensive, currently available corpus of source materials and carefully compared.

The production of the preliminary research results reported in this paper has been facilitated by the creation of an extensive, contextual database which permits the systematic study of the presently available extensive body of source texts. All attestations of contact-induced expressions along with the contexts of their use are recorded, making it possible to obtain frequency counts and chronological trajectories for individual words, and make distinctions by region and by year. This approach should eventually lead to a fuller picture of contact-induced change, refining the notion of how microand macroregional patterns of change developed in colonial Nahuatl and beyond. It will also make it possible to understand the rules of categorization and achieve precise linguistic descriptions. On a general level, the phenomena studied embrace lexical,

J. Lockhart, The Nahuas after the Conquest..., pp. 318-323.

S.G. Thomason, T. Kaufman, Language Contact, Creolization, and Genetic Linguistics, Berkeley 1988.

F. van Coetsem, Loan Phonology and the Two Transfer Types in Language Contact, Dordrecht 1988 (Publications in Language Sciences, 27).

$8 \quad$ S.G. Thomason, T. Kaufman, Language Contact, Creolization..., pp. 74-94; S.G. Thomason, Language Contact. An Introduction, Washington, D.C. 2001, pp. 70-71. 
phonological, morphological and syntactic changes, often occurring simultaneously or sequentially. All these language innovations reveal the nuances of the complex process of cross-cultural translation, the receptivity of European influence, the domestication of the new and survival of traditional language resources. This paper specifically discusses phenomena occurring on the level of lexicon.

\section{NEOLOGISMS}

Lexical phenomena include native creations, borrowing, meaning change and calques. The category of native creations, or neologisms, includes cases where a new word was created to name a new concept or object but without imitating a Spanish word. Neologisms are often produced by combining existing words or by giving words new suffixes or prefixes. This classification is often limited to those expressions that are in the process of entering language, but have not yet become part of its standardized vocabulary. It has been observed that resorting to neologisms was probably the most typical and widespread language reaction in the first phase of contact when the Nahuas relied mainly on the resources of their own language and borrowing was rare. ${ }^{9}$ We cannot be certain regarding the possible wider use of neologisms reported in early dictionaries; however, those that figure in texts produced by the Nahuas themselves indeed seem to point to vocabulary that entered everyday language. One of numerous examples is tlapohualtepoztli ("counting copper/iron"), used for "a striking clock," a word appearing in the municipal records in Tlaxcala in $1550,{ }^{10}$ and still attested toward the end of the seventeenth century in the annals of Zapata y Mendoza. ${ }^{11}$

It is becoming quite clear that the process of the coinage of neologisms continued well beyond the first stage of contact into times when noun borrowing became widespread; moreover, it continues as a common phenomenon in present varieties of $\mathrm{Na}$ huatl. For example tlacamazatl, meaning "man-deer" and used for a centaur, is first attested in the early seventeenth century compilation of native records by Chimalpahin: centaur de sagitario. ypan quicuepa centauro tlacamaçatl ("Sagittarius: they translate it as a centaur [or] person-deer"). ${ }^{12}$ As is obvious in this example, neologisms were still in use although loanwords designating the same things had already been incorporated. In fact they often accompany actual loanwords as an additional explanation. For example, in the Exercicio quotidiano by Fray Bernardino de Sahagún (ca. 1574), copied by Chimalpahin in the early seventeenth century, a neologism cuaubtlanenqueh (sg.

J. Lockhart, The Nahuas after the Conquest..., pp. 265-283.

10 J. Lockhart, F. Berdan, A.J.O. Anderson, The Tlaxcalan Actas. A Compendium of the Records of the Cabildo of Tlaxcala, 1545-1627, Salt Lake City 1986, p. 70.

11 J.B. Zapata y Mendoza, Historia cronológica de la Noble Ciudad de Tlaxcala, ed. and trans. by L. Reyes García, A. Martinez Baracs, México 1995, p. 160 (Colección Historia: Serie Historia de Tlaxcala, 4).

12 Codex Chimalpahin, trans. by S. Schroeder, A.J.O. Anderson, Vol. 2, Norman 1997, p. 128 (Civilization of the American Indian Series, 225). 
cuaubtlanenqui) is used in a specific context even if numerous loanwords appear in its immediate company:

- Auh otiquinmopanahuili yn ixquichtin tlaachpaitohuanime prophetasme. yn ixquichtin virginesme, yhuan in Martyresme yhuã in confessoresme, yhuan in quaubtlanenque

And you have exceeded all those who foretell, the prophets, all the virgins, and the martyrs, and the confessors, and the hermits. ${ }^{13}$

The appearance of the term cuaubtlanenqui ("one who lives in the woods"), along with another associated neologism, cuaubtlanemiliztli ("living in the woods") could perhaps be explained by a relatively early date of the original manuscript. In his writings Chimalpahin incorporates the loanword hermitaño ${ }^{14}$ and it also appears in another early, originally sixteenth-century text referring to the origins of the Mexica and copied by him. ${ }^{15}$

According to the linguistic definition, when a word or phrase is no longer new, it stops being a neologism, but in fact neologisms may take a long time, even decades to become "old." Thus, being able to say when and under what circumstances a word should no longer be considered a neologism seems to be highly problematic. Nahuatl texts reveal that many of the early introductions in fact continued into Stage 2 and beyond, that is, well into the seventeenth century, long after actual Spanish terms had been borrowed to designate the same concepts or objects. A good example is a very early and widespread neologism, cuaatequia ("to pour water on someone's head"), or "baptize," a term coined on the description referring to the physical act associated with baptism that remained in use at least till the first half of the eighteenth century (e.g. a 1738 will from Toluca, ${ }^{16}$ and a Nahuatl play Dialogue on the Apparition of Virgin Mary $\left.{ }^{17}\right)$. It is, however, extremely difficult to say when it was no longer a neologism in the linguistic sense. In addition, this word may have been part of normal everyday vocabulary before contact, later receiving its religious meaning. In modern Huastecan $\mathrm{Na}-$ huatl cuaatequia is used with its mundane, literal meaning, whereas baptism is referred to as cuaaltia ("to bathe someone's head") ${ }^{18}$.

The way native neologisms and corresponding Spanish loanwords were used next to each other implies that the Nahuas considered them synonyms. They were often employed in a very traditional way as part of difrasismos, or doublets, constructions in which two separate words are paired to form a single metaphoric unit, the paired words being either synonyms or antonyms. This semantic and stylistic device was commonly

13 Ibid., p. 162.

14 J. Lockhart, S. Schroeder, D. Namala (eds. and transl.), Annals of his Time. Don Domingo de San Antón Muñón Chimalpabin Quaubtlehuanitzin, Stanford 2006, p. 170 (Series Chimalpabin).

15 Codex Chimalpahin, trans. by S. Schroeder, A.J.O. Anderson, Vol. 2, p. 24.

16 C. Pizzigoni (ed. and trans.), Testaments of Toluca, Stanford 2007, p. 217 (Nabuatl Studies, 8. UCLA Latin American Studies, 90).

17 B. Sell, L. Burkhart, S. Poole (eds.), Nahuatl Theater, Vol. 2: Our Lady of Guadalupe, Norman 2006, p. 76.

18 John Sullivan, personal communication, November 2014. 
employed throughout preconquest Mesoamerica. In the context of language contact, the function of the native element in such pairs was probably originally to explain the meaning of the loan element. However, even if later one of the two elements often faded out, some of them became definitive, like -yoliya -anima ("one's spirit, one's soul"). An early example of the use of a Nahuatl-Spanish doublet comes from the Nahua periphery in Sonocusco: tobuelitiliz topoder [written as "touelitiliz topoler"], meaning ("our power"; petition from Huehuetlan, Soconusco, 1562, AGI, Guatemala 52, fol. 35r). It is possible, though difficult to confirm, that the Nahuatl term buelitiliztli was a new creation based on the verb hueliti ("to be possible") to approximate the Spanish concept of poder. If there had been a noun buelitiliztli before, its meaning would have probably been the ability to do something and not being empowered by someone else in the Spanish sense. In many other cases the native components of doublets are unequivocally neologisms. For example the expressions tetlechipabualoyan and tletechipabualoyan ("the place where people are purified by fire"), coined to convey the Christian concept of purgatory, continued to be employed well into the seventeenth century even though the Spanish word purgatorio is already attested in one of the testaments of Culhuacan 1580 (as purcatori). ${ }^{19}$ This neologism is often paired with the loanword purgatorio in traditional doublets:

- yn inpanpa in motlachihualtzitzinhuan in tlayohuiticate in tetlechipabualoyan = Purgatorio

On account of your creatures who are suffering in the place where people are purified by fire, purgatory (a religious play, ca. 1600-1650). ${ }^{20}$

- ma nalquiça y moJustiçiatzin yn itechcacopa yn ompa caten y motletenchipahuayatzinco y progāturio

May your justice reach unto those who are there in your place of fiery purification of people, purgatory (a religious play, ca. 1600-1650). ${ }^{21}$

As we can see, the following example provides yet another case of a doublet: ymecanelpiayatzin ycordontzin for a rope belt worn by Franciscans, where the neologism, a possessed instrumentive noun -mecanelpiaya(tzin) is used as a synonym of Spanish cordón (here with the Nahuatl reverential -tzin, just as the neologism with which it is paired) means a rope belt ("lit. an instrument for binding oneself with a rope"):

- yn ica ymecanelpiayatzin ycordontzin totlaçottatzin S. Fran \{co\}. quinmopalehuilia quimonmoquixtilia yn ompa tetlechipabualloyan Purgatorio

With his cord girdle, his rope belt, our precious father San Francisco helps them and extracts them from the place where people are purified by fire, purgatory. ${ }^{22}$

The longevity of a similar, slightly simplified version of the neologism and its

19 S.L. Cline, M. León Portilla (eds.), The Testaments of Culbuacan, Los Angeles 1984, p. 24 (Nahuatl Series, 1. Special Studies (UCLA Latin American Center Publications), 2).

20 B. Sell, L. Burkhart, G. Spira (eds.), Nahuatl Theater, Vol. 1: Death and Life in Colonial Nahua Mexico, Norman 2004, p. 178.

21 Ibid., p. 238.

22 J. Lockhart, S. Schroeder, D. Namala (eds. and transl.), Annals of his Time..., p. 240. 
widespread acceptance beyond more formal writing is attested by its use among the eighteenth-century inhabitants of a small town of Ixtenco (Tlaxcala; e.g. S. ${ }^{n}$ to Purgatorio yn tlachipabualoya [n], "Holy Purgatory, a place of purification", a will of María Juana, 1739, San Juan Ixtenco, Church Archive).

Neologisms were part of a broader phenomenon of describing and naming the 'new' based mainly on native language resources, but often complemented with additional qualifications derived from Spanish. An early parallel to later neologism-loanword pairings was the use of the term Caxtillan (adapted from Castilla according to the rules of Nahuatl) as the basic qualifying reference to things from Castile among the Nahuas in the first decades after the Spanish conquest. This early borrowing became a very useful and universal modifier of names and descriptions of introduced phenomena. It could form part of longer expressions, but was most commonly employed to coin compact identifications, consisting of a Nahuatl noun providing a recognizable parallel and the qualifying "Caxtillan" to make the distinction. Such terms were above all employed for new foods, artifacts and species. ${ }^{23}$ Thus, for example, rose became Caxtillan xochitl ("Castile flower"), garlic - Caxtillan xonacatl ("Castile onion"), sardine - Caxtillan michbuatzaltepiton ("little dried fish of Castile"). As we can see, this mechanism led to the change or extension of meaning of existing vocabulary facilitated by additional qualification.

\section{MEANING CHANGE}

Meaning change can take three basic forms depending on whether a given term adds new referents, reduces them or changes its basic referent, corresponding to the extension of meaning, narrowing, and shift. The latter case seems much more problematic, for it is often difficult to prove that a complete replacement took place on a larger scale, but it may well be the case of a particular speaker. Extensions of meaning based on adding new referents were very common and inevitable whenever functions, appearances or meanings of Nahuatl and Spanish objects and concepts were close enough. Thus, amatl, meaning native bark paper, was employed in reference to European paper, but, through extension, also designated a written document or a letter.

The extension of meaning sometimes entailed generalization or using a specific word with a broader meaning referring to a more general class of objects. For example tepoztli (originally meaning copper or bronze) was employed for all non-precious metals, while a loanword from Spanish, tomin, originally designating one eighth of a peso, took on the meaning of money in general. ${ }^{24} \mathrm{~A}$ possible example of a change of a referent is the case of tlacatecolotl, or "person-owl," the term widely used in colonial Nahuatl to refer to a Christian devil. It is assumed to have been a malevolent creature of minor importance in pre-conquest lore, therefore apparently favored by the friars as the term

23 J. Lockhart, The Nahuas after the Conquest..., pp. 276-277.

24 Ibid., pp. 272-273, 297-928. 
for devil. ${ }^{25}$ It is difficult to say if this change of a reference was indeed a widespread and complete one, for in native devotional texts apparently less controlled by ecclesiastics, the Nahuas often tended to identify devil as tzitzimitl, a fearful stellar demon threatening the world and its inhabitants, especially during solar eclipses. The survival of the pre-conquest concept of tlacatecolotl in spite of centuries of Christianization is attested among the modern Nahuas of Veracruz, who identify this creature as a powerful spiritual entity in charge of their sacred mountain. ${ }^{26}$ It is thus conspicuous that in many cases the Nahuas retained older meanings along with new "Christianized" ones or ignored new terminological equivalents promoted by friars.

The interplay between native terms acquiring new meanings, neologisms coined to respond to the new reality, and borrowings from Spanish is markedly visible in the terminology referring to new ethnic groups, such as Africans. The first and most common term for them was an extension of a native term tliltic, "black one," which seems to have been a neutral designation. Though this is a word that could have arisen from direct observation of the people in a way typical of Stage 1, it is also possible that it was a translation of the Spanish negro. A very widespread and prolonged use of the plural form of tliltic, tliltiqueh (present in the analyzed sources from ca. 1550 until the end of the seventeenth century) did not exclude, however, the adoption of a loanword negro attested already in $1556^{27}$ and as late as in the annals of Puebla in the late seventeenth century, ${ }^{28}$ where it is used as a note on a margin of an entry employing the term tliltiqueh.

Moreover, in a Nahuatl play from the seventeenth century the Africans are called cacatzactin ${ }^{29}$ meaning "dirty ones" and implying derogative associations. The same term appears already in the second half of the sixteenth century in the Florentine Codex in reference to the arrival of the Spaniards: Ic notzaloque, ic tocaiotiloque, teteu ilhujcac vitze: aub in tliltique teucacatzacti mjtoque ("They were called, they were named 'gods come from heaven'. And the blacks were said to be dirty gods"). ${ }^{30}$ Indeed, the meaning of this word seems to exceed the simple association with a dark color. In his vocabulary Molina translates the related agentive "adjective" catzahuac as "a dirty thing" (cosa sucia), while its root, the verb catzahua, is "to get dirty" (catzaua pararse sucio. ni no. ensuziarse. nite. ensuziar a otro). ${ }^{31}$ Catzahuac was also commonly used in devotional Christian writing to refer to moral filth. This was apparently true also in native writ-

25 L. Burkhart, The Slippery Earth. Nahua-Christian Moral Dialogue in Sixteenth-Century Mexico, Tucson 1989, pp. 40-41.

26 Victoriano de la Cruz Cruz, personal communication 2012.

27 J. Lockhart, F. Berdan, A.J.O. Anderson, The Tlaxcalan Actas..., p. 152.

28 C. Townsend (ed. and trans.), Here in This Year. Seventeenth-Century Nabuatl Annals of the Tlaxcala-Puebla Valley, Stanford 2010, p. 126.

29 B. Sell, L. Burkhart, S. Poole (eds.), Nahuatl Theater, Vol. 2, pp. 152-153.

30 Bernardino de Sahagún, The Florentine Codex. General History of the Things of New Spain, trans. by C.E. Dibble, A.J.O. Anderson,. Book 12: The Conquest of Mexico, Santa Fe 2012, p. 21 (Monographs of the School of American Research, 14).

31 Fray A. de Molina, Vocabulario en lengua mexicana y castellana [1571], Mexico 2001, fol. 12v (Biblioteca Porrúa, 44). 
ings: catzahuac is employed as a synonym of tliltic, both referring to the contamination by sin: "I, the sinner, the dirty one, the black one" ( $y$ nitlatlacobuani y nicatzabuac $y$ nitliltic ${ }^{32}$ ), implying that these terms, used as ethnic designations, were in fact loaded with a negative, moral valuation for the Nahuas. Certain derogatory connotations are also carried by a loanword cimarrontin (from cimarrón), or renegades, employed by Chimalpahin in reference to the tiltiqueh: ypampa yub mibtobuaya vmpa buallazque in ilhuicaatenco in huey atenco acapolco omotlallique cimalonti tliltique ("because it was said that the black renegades who had established themselves at Acapulco would come from the seashore"). ${ }^{33}$ Interestingly enough, this loanword survives in modern Huastecan Nahuatl as a reference to savage or raw qualities, e.g. unbaptized and savage persons, undomesticated animals and wild plants which do not bear fruit. ${ }^{34}$

\section{LEXICAL BORROWING}

Loanwords are perhaps the most immediately visible and patent signs of language change. In addition to borrowings consisting of single Spanish words, loan phrases form a somewhat different subcategory of lexical borrowing. These are unanalyzed expressions borrowed as a whole, like alcalde mayor, Audiencia Real, Viernes Santo, vispera de, cadena de oro, la ciudad, or a la china (meaning "China, the Philippines" in Stage 2). Once a loan was incorporated, it underwent phonetic and morphological adaptations according to the rules of Nahuatl: thus, for example, imagen was reinterpreted as magen or maxen, losing the initial vowel identified by the Nahuas as the subordinating particle in, while regidor could become lexitol complying with native phonology. ${ }^{35}$ Sometimes loanwords become independent entities whose meaning was no longer directly connected with Spanish, as with telocatolio, originally from interrogatorio or "questionnaire," but meaning the "true title" (usually for land ${ }^{36}$ ). Sometimes the semantic transformations of a loanword were apparently short-lived or transitory, resulting from a misunderstanding of the precise meaning of a foreign term. Thus, escritura ("writing" or "scripture") used in its new meaning referring to a writing desk is attested in Colhuacan around 1580 ( $\mathrm{Auh}$ nica momachiotia yn noya teopan ontetl Caja y huan çentetl Escritura tzaccayo yhuan mesa buey abuehuetl yhuan escallera; "And here is manifested what there was in the church: two chests, a writing desk with a latch, a big table made of willow wood, a ladder"). ${ }^{37}$ Another example is that of the rather rarely attested loanword enemigo, not adopted for the basic meaning of "enemy" (a word already present in Nahuatl), but present in the annals of Puebla in a narrower sense of a synonym for Englishmen:

32 John Carter Brown Library, Cod. Ind. 7, fol. 43r.

33 J. Lockhart, S. Schroeder, D. Namala (eds. and transl.), Annals of his Time..., p. 184.

34 Victoriano de la Cruz Cruz, personal communication, September 2012.

35 F. Karttunnen, J. Lockhart, Nahuatl in Middle Years...

36 J. Lockhart, The Nahuas after the Conquest..., p. 298.

37 S.L. Cline, M. de León Portilla (eds.), The Testaments..., p. 4. 
- Sanno ypan xibuitl ynic matlactli omey 13 tonali mani metztli mayo yn obuasico tlanabuatili amatl ypan tonali Juebes yn iuh quitotibuitz ye Oca Enemigos yngleses yn beraCruz

In this same year, on Thursday, the $13^{\text {th }}$ day of the month of May, there arrived a dispatch saying that English enemies were in Veracruz.

- aub yn omoquixtisquia ypan tonali lunes niman yman isiubca obuasico yn tlanahuattili ynic aocmo mohuicas ypanpa ye otzinquisque yn enemigos ye atlan cate ynic quitocayotica sacrifisio

They were going to leave on Monday, but then at that moment there suddenly arrived a dispatch that they should go no longer, because the enemies [the Englishmen] had pulled back and were already at sea, at what they called Isla Sacrificios.

- Sanno ypan xibuitl ynic caxtolli onnabui 19 tonali mani metztli agosto pan (sic) domingo yn ohuasico tlanabuatili ynic ye oquintlanq yn onpa canpech yn enemigoz In this same year, on Sunday the $19^{\text {th }}$ day of the month of August, there arrived a dispatch that the enemy [the Englishmen] had defeated [the people] in Campeche. ${ }^{38}$

These examples show how the borrowing of ethnic terms was accompanied by the infiltration of Spanish ideas and cultural prejudices. It is meaningful that another synonym for Englishmen (inglesestin or inglatera tlacah), or more precisely English pirates heretics - was employed both as a loanword hereje and as a neologism chicotlaneltocani ("crooked believer") that directly explains the foreign word:

- yn quintocayotia inglesestin inglatera tlaca tlabueliloque chicotlaneltocanime motenehua Eregesme

They call them Englishmen, people from England, wicked people, crooked (wrong) believers called heretics. ${ }^{39}$

Moreover, the borrowing track could have been more complex than a simple unidirectional Spanish-Nahuatl influence. Occasionally original native loanwords borrowed into Spanish later came back to Nahuatl as a result of intense interplay with the other side, accompanied by a change of meaning or connotations of the term. Thus, the ethnic loanword from Nahuatl to Spanish, chichimecatl, actually comes back to Nahuatl from Spanish as chichimeco, and gains in importance during the Chichimeca war waged in the northern regions. The Annals of Puebla report that in 1633 an epidemic called chichimeco broke out, reportedly brought from the "Chichimec" area: tlatlasistli Quisaco ytoca chichimeco miyec tlacatl y omomiquili ("a cough called chichimeco broke out, many persons died")..$^{40}$ In a petition from Coatlan de Puertos Abajo in Jalisco written in 1637 chichimeco appears in the Nahuatl document as a synonym for pagan: oc tlapanaubti çenca techtolini maca çan yoquin tiyahoua(n), ypan techmati yoqui tichichimeco ypan techmati yoquin amo tichristianos ("it is excessive how very much he mistreats us,

38 C. Townsend (ed. and trans.), Here in This Year..., p. 124, 126, 134.

39 J. Lockhart, S. Schroeder, D. Namala (eds. and transl.), Annals of his Time..., p. 281.

40

C. Townsend (ed. and trans.), Here in This Year..., pp. 94-95. 
as though we were his enemies, he considers us like Chichimecs, he treats us as if we weren't Christians"). ${ }^{41}$

Loanwords, once incorporated into Nahuatl, were subject to numerous derivational processes, often leading to new lexical categories and grammatical functions. For example traditional suffixes were commonly employed to form abstract or collective nouns (teniente, "deputy," becoming tenienteyotl meaning "the office of a deputy") or denominal verbs (firma, "a signature" leading to firmatia, "to sign"; sabadoti, "to be Saturday" from sabado, "Saturday"), among a very rich pool of possibilities. Nahuatl suffixes referring to size and carrying positive or negative associations were frequently applied to borrowed terms and used in the same ways as with native words of similar categories. Thus, a common loanword judio ("Jew") was sometimes enriched with suffixes traditionally used with ethnic terms to give them a derogatory meaning (as in the case of the purely Nahuatl term otompol, "a wretched Otomi"), becoming judiopopol ("wretched Jews"). ${ }^{42}$

The relatively uncommon addition of imported affixes to native stems seems to point to a more complex and sustained interaction between the two languages. This is especially the case of backward borrowings, that is, native words adapted by Spaniards and coming back in a transformed form to the speakers of Nahuatl. Thus, chocolatera, a chocolate vendor, created from xocolatl and the Spanish suffix -era, is attested in a 1650 Nahuatl will from Xochimilco. ${ }^{43}$ Its use among Nahuatl speakers attests to the degree of intensity of language exchange between the two sides. At one place in his work, Chimalpahin makes a reference to the sellers of cacao as yn cacahuanamacaque cacavateros [cacahuateros] españoles ("Spanish sellers of cacao, cacao vendors") ${ }^{44}$, a traditional Nahuatl doublet construction usually based on the use of two synonyms or closely related terms.

A separate category consists of combinations of morphemes of different origin, corresponding to the linguistic category of blends and based on Spanish and native stems merged into one new word designating foreign concepts, personnel or objects. Thus, it is common to find names of new professions, such as bolsanamacac ("bag seller") or candelachiuhqui ("candlemaker"), new materials and elements of material culture, such as letrachibualoni ("writing medium" for a kind of ink) or xocpalguantes ("foot-gloves" for footwear of the Japanese), new plants (aceitunasquabuitl, "olive tree") or functions (cabildotlacatl, "cabildo person," for municipal officials). Some of them were clearly created $a d$ hoc and did not enter language on a bigger scale. Thus, cibuamadre based on cibuatl ("woman") in Nahuatl, combined with the Spanish word for mother

$41 \quad$ McAfee Collection, 339.

42 Biblioteca Nacional de Mexico, MS 1476, Santoral en mexicano, Oraciones de Nuestra Señora; L. Burkhart, Before Guadalupe. The Virgin Mary in Early Colonial Nabuatl Literature, Albany 2001, p. 96 (IMS Monograph, 13).

43 T. Rojas Rabiela, E.L. Rea López, C. Medina Lima (eds.), Vidas y bienes olvidados. Testamentos indígenas novohispanos, Vol. 3: Testamentos en nahuatl y castellano del siglo XVII, México 2002, p. 239 (Historias (Centro de Investigaciones y Estudios Superiores en Antropología Social)).

44 J. Lockhart, S. Schroeder, D. Namala (eds. and transl.), Annals of his Time..., p. 240. 
was employed for a nun by the authors of the already mentioned devotional manuscript. ${ }^{45}$ Diotatzin (Diostatzin, "God Father") is apparently only attested in a 1726 will from Toluca, ${ }^{46}$ while tlacatl, "person," combined with Spanish juez, or "judge," to form tlacajuez designating a census taker, appears in the late-seventeenth-century annals of Tlaxcala. ${ }^{47}$ Reflecting this tendency, also a common pairing of -anima and -yoliya, "soul and spirit" referring to a Christian soul, could blend into a single word, yolliaaniman/ -yolliaanima. ${ }^{48}$

\section{CALQUES}

Contact-induced phenomena also embrace literal or word-to-word translations of foreign idiomatic expressions, or calques. An illustrative example comes from one of the documents copied by Chimalpahin, a 1564 letter by Juan de San Antonio, grandson of Nezahualpilli. It translates the Spanish metaphors, "waters of falsehood" and "bread of lies," by constructing an extension identifying tlaxcalli with bread, and resulting in the coinage of "the tortilla of lies": yn oquimititia yn oquimoqualtitia yn oquimotzopelicamachititia yn oquimahuiyacamachititia yn iztlacaatl yn iztlacatlaxcalli ym mitoua ym moteneua pan de mentira, mala ganancia, maldicion ("who drank the waters of falsehood and found them sweet, who ate the bread of lies and found them pleasant; what are called and known as 'pan de mentira,' 'mala ganancia,' 'maldición”').49

Closely related is a large group of formulaic translations, especially ubiquitous in religious contexts. Thus cemihcac ichpochtli stood for Eternal Virgin, ilhuicac tlabtocayotl for the Kingdom of Heaven or yancuic cemanabuac for the New World. All of these Nahuatl expressions were built on existing vocabulary but appear in phraseological units which would not make much sense without their European referents.

The notion of a calque can be further extended to the so-called equivalence relationships, corresponding well with the concept of lexico-syntactic calques changing semantic and/or grammatical features of the target language and leading to an innovative use of native words and expressions in new constructions and/or syntactic contexts. Among the earliest and most common were piya, originally "to guard" becoming a counterpart of tener, "to have," and quenamih (originally meaning "how, in a certain manner") that formed an equivalence relationship with como ("how, as, like)". 50 Such equivalence relationships could lead to the redefinition of a native term as a new lexical

\footnotetext{
45 John Carter Brown Library, Cod. Ind. 7.

46 C. Pizzigoni (ed. and trans.), Testaments..., p. 157.

47 C. Townsend (ed. and trans.), Here in This Year..., pp. 182-188.

48 A will from Colhuacan, 1581: S.L. Cline, M. de León Portilla (eds.), The Testaments..., p. 142; also an early seventeenth-century copy of a religious treatise compiled by Sahagún in 1574: Codex Chimalpahin, Vol. 2, p. 166.

49 Ibid., Vol. 2, p. 238.

50 J. Lockhart, The Nahuas after the Conquest..., pp. 313-315.
} 
category, as was the case of the noun tocaitl ("name"), that started to be used as a verb, an equivalent of the Spanish llamar. Thus, the expression ninotoca [Juan] would be an exact counterpart of "me llamo [Juan]", replacing the traditional notoca [Juan] ("my name [is] [Juan])". Prolonged contact across several centuries resulted also in numerous morphological, phonological and syntactic adaptations that embrace for example the pluralization of inanimate nouns (though even in modern variants of Nahuatl not completely replacing traditional pluralization limited to animate objects) or the new roles of tlen/tlein acquiring the functions of Spanish que as a subordinator and even as an equivalent of the Spanish de. Many of these phenomena, spurred by a growing presence of bilingual speakers, were typical for Stage 3 and extend in significant ways to modern variants of Nahuatl that reveal different degrees of exposure to Spanish impact and different states of contact-induced change.

\section{CONCLUDING REMARKS}

What is emerging from the initial step in the systematic study of contact phenomena in older Nahuatl is a complex picture that needs to involve local variants, conditions of change, degrees of exposure to Spanish and long-term linguistic strategies of native speakers. This can be achieved by studying a broad sample of colonial sources, heterogeneous in terms of genre, date and provenience; and these should be complemented by modern ethnolinguistic data. The micro-regional trajectories need to be compared in order to grasp wider macro-regional trends, extending to surviving modern variants of Nahuatl. It is already clear that the use of certain phenomena will vary among different users of Nahuatl, depending on whether they are more acculturated, bilingual speakers or monolingual members of native communities. For example, this complexity is evident in the writings of a native annalist living in Mexico-Tenochtitlan, don Domingo de San Anton Muńon Chimalpahin Quauhtlehuanitzin. He employs an enormous amount of both Spanish loanwords and Nahuatl neologisms (many of which could have been created $a d$ hoc by himself) that surely were not in use to the same extent among the actual speakers in communities outside the metropolis or even by most of the Nahuas living within it. Chimalpahin's writings also attest to a certain fluidity in the timing of contact phenomena. For example, although the adoption of kinship terms was generally a late, Stage 3 phenomenon, ${ }^{51}$ in his annals referring to contemporaneous events taking place in Mexico-Tenochtitlan Chimalpahin happens to use (but only once!) a Spanish kinship term primo hermano "first cousin": (iyachton yPrimo hermano, "her older brother, first cousin") in reference to a native noblewoman, doña Agustina de Guzmán from Coyoacan..$^{52}$ In fact, the compilation of records bearing similarities of Chimalpahin's works attests another Spanish kinship term that forms part of a combined loanword yprimoteyccauh, composed of primo and the Nahuatl

51 Ibid.

52 J. Lockhart, S. Schroeder, D. Namala (eds. and transl.), Annals of his Time..., p. 252. 
term teiccaub ("younger brother or male cousin"), together conveying the meaning of a "younger cousin," 33 as well as prima hermana ("first (female) cousin"), both referring to the members of the native nobility. ${ }^{54}$ These examples show that sometimes the use of language among particular users or groups could have been well ahead of more general patterns. This may have been the case with subregional variations - including both central Mexican variants and peripheral Nahuatl zones - that diverge in some ways from Valley of Mexico phenomena. Only systematic research based on the currently available bodies of local documents can indeed show convergences and divergences across time.

The most recent discoveries in the constantly emerging corpus of Nahuatl texts reveal the relatively late timing of certain phenomena in the zones of intense cross-cultural contact, significantly posterior when compared with other regions where native-Spanish interaction was to all appearances less intense. These later-than-expected phenomena are emerging in the testaments of Coyoacan, ${ }^{55}$ one of the major indigenous entities in the Valley of Mexico, and they are in accordance with similar results reported in the testaments from Toluca, ${ }^{56}$ the major valley also characterized by considerable Spanish population and settlement. On the other hand, the study of petitions from Jalostotitlan in peripheral western Mexico ${ }^{57}$ shows that some changes were in operation here earlier, in spite of the remoteness of the zone with respect to the core of European colonization. Equally interesting implications are emerging from the Nahuatl texts of the remote southern region of Soconusco in Chiapas, preserved in the Archivo General de Indias, in Seville. ${ }^{58}$ In spite of the fact that this region is far from the major centers of Spanish occupation, these documents reveal a huge density of Spanish loanwords as early as in 1560s. In addition, both of these cases, Jalisco and Chiapas, illustrate language change in Nahuatl where it was not a dominant language, even though its use predated the Spanish conquest. It is clear then that the study of the Nahua periphery, in colonial times and today, will considerably enrich and refine our picture of cross-cultural interactions on the level of language and culture itself.

As has been shown, language data related to contact-induced change reveal the parallel, prolonged use of neologisms and loanwords, the widespread "Nahuatlization" of foreign terms, as well as the adoption of Spanish ideas and cultural stereotypes. It is clear that numerous neologisms reported in dictionaries, such as the works of Molina, cannot be taken as a straightforward reflection of language use in native communities. Many such terms were created $a d$ hoc as explanations of Spanish words or names for new objects and concepts and did not spread among the normal users of Nahuatl. Thus, the de-

53 Codex Chimalpabin, Vol. 2, p. 92.

54 Ibid., Vol. 2, p. 104.

55 R. Horn, 'The Testaments of Coyoacan', a paper presented at the Annual Meeting of the American Society for Ethnohistory, 20 October 2012, Pasadena.

56 C. Pizzigoni (ed. and trans.), Testaments...

57 J. Sullivan, 'The Jalostotitlan Petitions, 1611-1618' in J. Lockhart, L. Sousa, S. Woods (eds.), Sources and Methods for the Study of Postconquest Mesoamerican Ethnohistory, provisional version, Wired Humanities Project, University of Oregon, 2007, at <http://whp.oregon.edu/Lockhart/Sullivan.pdf>.

Archivo General de Indias, Guatemala 52. 
gree of the correspondence between dictionary repertories and language use needs to be verified with data found in mundane texts written by the Nahuas themselves. Another urgent need consists of comparing the post-contact religious terminology employed in texts written by native authors with those authored or compiled by ecclesiastics, hopefully leading to a thorough assessment of the native and Spanish roles in the creation of "Christian Nahua vocabulary." This requires a close examination of how these terms were employed in reference to pre-conquest contexts. Whenever we are able to substantiate the existence of pre-conquest equivalents of Christian terms, we gain a further glimpse into what may be a greater degree of communication between the two sides and a greater comprehension on the part of the Nahuas, than has generally been assumed.

This approach involves the real challenge of reaching beyond the simple identification of emerging differences in language change, to trying to understand, on the one hand, how reconstructed regional patterns relate to the local trajectories of major historical processes, and on the other hand, what factors influenced the nature and speed of cultural transformations. Vocabulary differences are often symptomatic of overall cultural differences and it is through language change, documented in a surviving corpus of texts, that we will be able to grasp the subtleties and mechanisms of culture contact and significantly refine our understanding of the past. Thus, research beginning with the identification of transfers in language has great potential for exploring the substance of cross-cultural transfer and the essence of its development, thus constituting a fundamental method for the study of culture and its transformations.

\section{ACKNOWLEDGMENTS}

The research leading to the results presented in this paper was financed by the Foundation for Polish Science within its Focus Programme and has subsequently received funding from the European Research Council under the European Union's Seventh Framework Programme (FP7/2007- 2013)/ERC grant agreement No. 312795. Much of the source material discussed here has been analyzed and classified by Julia Madajczak and Agnieszka Brylak within the project's database. I would like to express my deep gratitude James Lockhart for his invaluable remarks on the early draft of this paper. Jim passed away in January 2014. I would also like to thank Marcin Kilarski and John Sullivan for their comments on the final version of this article.

\section{BIBLIOGRAPHY}

Archivo General de Indias, Guatemala 52.

Biblioteca Nacional de Mexico, MS 1476, Santoral en mexicano, Oraciones de Nuestra Señora.

Biblioteca Nacional de México, Ms. 1487.

John Carter Brown Library, Cod. Ind. 7.

McAfee Collection, 339. 
Bernardino de Sahagún, The Florentine Codex, trans. by C.E. Dibble, A.J.O. Anderson, pt. 13. Book 12: The Conquest of Mexico, Santa Fe 2012 (Monographs of the School of American Research, 14).

Burkhart L., Before Guadalupe. The Virgin Mary in Early Colonial Nabuatl Literature, Albany 2001 (IMS Monograph, 13).

Burkhart L., The Slippery Earth. Nahua-Christian Moral Dialogue in Sixteenth-Century Mexico, Tucson 1989.

Canger U., Mexicanero de la Sierra Madre Occidental, México 2001 (Archivo de Lenguas Indigenas de México, 24).

Cline S.L., León Portilla M. (eds.), The Testaments of Culhuacan, Los Angeles 1984 (Nahuatl Series, 1. Special Studies (UCLA Latin American Center Publications), 2).

Codex Chimalpahin, trans. by S. Schroeder, A.J.O. Anderson, Vol. 2, Norman 1997 (Civilization of the American Indian Series, 225).

Flores Farfán J.A., Cuatreros somos y toindioma hablamos. Contactos y conflictos entre el nábuatl y el español en el sur de México, Tlalpán, D.F. 1999 (Lengua-jeș).

Flores Farfán J.A., 'The Hispanization of Modern Nahuatl Varieties' in Hispanisation. The Impact of Spanish on the Lexicon and Grammar of the Indigenous Languages of Austronesia and the Americas, Berlin-New York 2008 (Empirical Approaches to Language Typology, 39).

Hill J., Hill K.C., Speaking Mexicano. Dynamics of Syncretic Language in Central Mexico, Tucson 1986.

Horn R., 'The Testaments of Coyoacan,' a paper presented at the Annual Meeting of the American Society for Ethnohistory, 20 October 2012, Pasadena.

Jensen A., 'Hispanisation in Colonial Nahuatl?' in T. Stolz, D. Bakker, R. Salas Palomo (eds.), Hispanisation. The Impact of Spanish on the Lexicon and Grammar of the Indigenous Languages of Austronesia and the Americas, Berlin-New York 2008 (Empirical Approaches to Language Typology, 39).

Karttunen F., Lockhart J., Nahuatl in Middle Years. Language Contact Phenomena in Texts of the Colonial Period, Berkeley 1976 (University of California Publications in Linguistics, 85).

Lockhart J., The Nahuas after the Conquest. A Social and Cultural History of the Indians of Central Mexico, Sixteenth Through Eighteenth Centuries, Stanford 1992.

Lockhart J., Berdan F., Anderson A.J.O., The Tlaxcalan Actas. A Compendium of the Records of the Cabildo of Tlaxcala, 1545-1627, Salt Lake City 1986.

Lockhart J., Schroeder S., Namala D. (eds. and transl.), Annals of his Time. Don Domingo de San Antón Muñón Chimalpahin Quaubtlehuanitzin, Stanford 2006 (Series Chimalpahin).

Molina A. de, Vocabulario en lengua castellana y mexicana y mexicana y castellana, Mexico 2001 (Biblioteca Porrúa, 44).

Pizzigoni C. (ed. and trans.), Testaments of Toluca, Stanford 2007, p. 217 (Nabuatl Studies, 8. UCL A Latin American Studies, 90).

Rojas Rabiela T., Rea López E.L., Medina Lima C. (eds.), Vidas y bienes olvidados. Testamentos indigenas novohispanos, Vol. 3: Testamentos en nahuatl y castellano del siglo XVII, México 2002 (Historias (Centro de Investigaciones y Estudios Superiores en Antropología Social)).

Sell B., Burkhart L., Poole S. (eds.), Nahuatl Theater, Vol. 2: Our Lady of Guadalupe, Norman 2006. 
Sell B., Burkhart L., Spira G. (eds.), Nahuatl Theater, Vol. 1: Death and Life in Colonial Nabua Mexico, Norman 2004.

Sullivan J., 'The Jalostotitlan Petitions, 1611-1618' in J. Lockhart, L. Sousa, S. Woods (eds.), Sources and Methods for the Study of Postconquest Mesoamerican Ethnohistory, provisional version, Wired Humanities Project, University of Oregon, 2007, at <http://whp.oregon. edu/Lockhart/Sullivan.pdf>.

Thomason S.G., Language Contact. An Introduction, Washington, D.C. 2001.

Thomason S.G., Kaufman T., Language Contact, Creolization, and Genetic Linguistics, Berkeley 1988.

Townsend C. (ed. and trans.), Here in This Year. Seventeenth-Century Nahuatl Annals of the Tlaxcala-Puebla Valley, Stanford 2010.

Zapata y Mendoza J.B., Historia cronológica de la Noble Ciudad de Tlaxcala, ed. and trans. by L. Reyes García, A. Martinez Baracs, México 1995 (Colección Historia: Serie Historia de Tlaxcala, 4).

Dr hab. Justyna OLKO - Researcher at the Faculty of "Artes Liberales", University of Warsaw, specializing in preconquest and postconquest Mesoamerican ethnohistory and Nahua philology. Author of several books, including Turquoise Diadems and Staffs of Office. Elite Costume and Insignia of Power in Aztec and Early Colonial Mexico (Warsaw 2005), Meksyk przed konkwista (Warsaw 2010, Klio Award 2010) and Insignia of Rank in the Nahua World. From the Fifteenth to the Seventeenth Century (Boulder 2014). Director of the team research projects "Language Encounters between the Old and New Worlds" (Foundation for Polish Science, Focus Program, 2010-2013), "Europe in America in Contact" (ERC Starting Grant, 2013-2018) and "Endangered Languages. Comprehensive models for research and revitalization" (National Programme for the Development of the Humanities, 2013-2016). 